\title{
Wh-pronoun and complementizer relative clauses: unintegration features in conversational Polish
}

\begin{abstract}
The paper examines syntactic features of non-canonical relativization in spoken Polish that loosen the structural integration of two types of relative clauses - one introduced by the complementizer $c o$, the other by the wh-pronoun ktorry. The resulting unintegration holds between the head NP and the co/który clause and contrasts with the integrated structure of canonical relatives. I discuss the range of unintegration features observed for both types in corpus data and indicate the distinct quantitative extents to which the two types are unintegrated. Although the nature of spontaneous conversation is such that it imposes some loosening of structural cohesion in both types, co clauses (especially non-subject relative clauses) are far more frequently unintegrated than który clauses. Also, co clauses depart functionally from the canonical relative structure in that the complementizer co serves functions other than that of a straightforward relativizer, namely it has conjunction-like uses (temporal, spatial, and general conjunction), indicating an expansion of the categorial status of $c o$. The observed unintegration of Polish conversational relatives is in line with previous analyses of the syntax of unplanned speech (e.g. Miller and Weinert 1998).
\end{abstract}

\section{Keywords}

spontaneous speech, unintegrated syntax, conversational spoken Polish, complementizer relative clauses, $w h$-pronoun relative clauses, non-canonical relativization

\section{Streszczenie}

Celem niniejszego artykułu jest analiza dwóch typów zdań względnych w mówionym języku polskim - tj. wprowadzanych przez zaimek względny któr-y oraz przez nieodmienny relator co. Głównym obszarem zainteresowania są niekanoniczne konstrukcje, w których obserwuje się rozluźnioną integrację akomodacyjną pomiędzy grupą rzeczownikową a zdaniem względnym. Dla obu wskaźników zespolenia (który i co), tekst omawia poszczególne typy cech formalnych, które powodują taką niezintegrowaną strukturę. Analiza danych korpusowych pozwala również na ilościowe określenie stopnia dezintegracji w obu typach zdań. Mimo że spontaniczny język mówiony wymusza pewną dozę dezintegracji $\mathrm{w}$ obu przypadkach, zdania względne $\mathrm{z}$ co (zwłaszcza te $\mathrm{w}$ funkcji innej niż podmiot) znacznie częściej charakteryzują się taką właśnie budową. Zdania z co odbiegają od kano- 
nicznej relatywizacji jeszcze w innym sensie: oprócz funkcji relativum generale, co może pełnić inne funkcje semantyczne, takie jak spójniki podrzędne miejsca i czasu (porównywalne $\mathrm{z}$ gdzie i kiedy) lub spójnik ogólnego zastosowania. Tego rodzaju użycia wskazują na ekspansję statusu kategorialnego co. Zaobserwowane zjawiska pokrywają się z doniesieniami innych autorów badających składnię spontanicznego języka mówionego (Miller and Weinert 1998).

\section{Słowa kluczowe}

spontaniczny język mówiony, luźna integracja składniowa, niekanoniczne zdania względne, nieodmienny relator, zaimek względny

\section{Introduction ${ }^{1}$}

\subsection{Unintegration: explaining the term}

Unintegration is an important property of spontaneous speech distinguishing it from (formal) written language. Miller (2006: 683) contrasts integrated and unintegrated syntax in the following $w h$-cleft constructions.

(1) What they will do is use this command to save the data (integrated)

(2) right, well, what you're doing is you're drawing a line (unintegrated)

Example (1), Miller explains, is integrated in that the post-copular complement clause (use this command...) depends on the wh-clause for tense, aspect, and subject NP. On its own, it has none of these. It is thus closely anchored or integrated into the wh-clause. On the other hand, example (2) is unintegrated in that the clause following the copula has its own tense, aspect and subject, which need not be identical to those of the wh-clause (e.g. what we can do is you will...) (Guz 2015). The integrated/unintegrated distinction may be further illustrated with the relative constructions in (3) and (4) (from Miller 2006: 681).

(3) If you've got some eggs about whose age you're not sure here's a useful test (integrated)

(4) If you've got some eggs you're not sure about their age here's a useful test (unintegrated)

In (3), the relative clause about whose age you're not sure is anchored to its head NP, i.e. some eggs. It is integrated into the head through a tight network of grammatical relations: whose is a relative pronoun referring back to eggs, and

${ }^{1}$ I would like to thank the editor of SPL and the two anonymous reviewers for their helpful comments, questions, corrections, and constructive criticism. 
through its genitive case it also conveys the genitive idea 'the age of the eggs'; also, about whose age is the complement of sure.

In (4), the relative clause is not - in Miller's terms - integrated into the head. There is not a relativizer to connect the head and the relative clause, and the latter is a gapless clause complete with its own subject and object. There is no gap normally expected in relatives. Also, the word order of you're not sure about their age is that of a complete clause, unlike in (3). All in all, while (3) is integrated, (4) is unintegrated.

Miller and Fernandez-Vest (2006) argue that such unintegrated blocks of syntax found in speech should be treated on their own terms - treated as target structures in spontaneous speech - rather than as degraded realizations of an ideal complex of clauses neatly connected into a sentence such as would be expected in carefully structured written language. This is also the position defended in Enkvist (1982), Miller and Weinert (1998), Hopper and Thompson (2008), and Callies (2012). Hopper and Thompson (2008: 109) argue that instead of viewing non-canonical conversational wh-clefts (such as (2)) as a degenerate variety of the canonical $w h$-cleft construction, "linguists would be better advised to consider the written pseudocleft [i.e. $w$ h-cleft] construction a normativized version of the what-fragment found pervasively in interaction." Miller and Weinert (1998: 293) and Callies (2012: 12) seem to agree with it in that they suggest that the classical integrated pattern may be a special development of written language.

\subsection{Który and co relative clauses in Polish}

In Polish, standard relative clauses introduced by the relative wh-pronoun któr-y 'who/which' (inflected in któr-a, któr-e, etc.) contrast with a colloquial variety of relative clauses introduced with the uninflected relative marker co 'that', as in (5). The head noun may be the subject or object of the relative clause, as in (5) and (6) respectively.

(5) $\mathrm{Ci}$ ludzie, którzy/co tu przychodzą these people who/co here come-3PL 'These people who/that come here'

(6) Te jabłka które/co masz tu na stole these apples which/co have-2sG here on table 'These apples which/that you have here on the table'

The discussion of co clauses often revolves around the problem of encoding grammatical relations such as case, gender, and number, which can be expressed overtly in the relative pronoun który, but cannot in the uninflected co. An important fact that underpins perhaps any comparison of co and który 
clauses is that the uninflected relative marker makes co relatives less integrated than który relatives. Consider the load of information encoded in która in (7), which is overtly marked for singular number and feminine gender to agree with the head ta sukienke 'this dress'. The wh-pronoun is also accusativemarked for the purposes of co-indexation with the trace position in the relative clause.

(7) Pożycz mi tę sukienkę którą/ co kupiłaś $t$ lend me this dress-ACC-SG-F which-ACC-SG-F/ Co bought-2sg [trace-ACC] 'Lend me the dress which/that you bought'

The same sentence is still acceptable/grammatical with the uninflected $c o$, but the connectivity and syntactic integration of the two clauses is not as tight as with która. On the replacement of która with co, the nuanced network of grammatical connections is gone. Thus co relatives are inherently marked by looser structure compared to their który counterparts.

The combination of the loose integration of $c o$ relatives and the fact that they belong in colloquial style is no coincidence: unplanned speech has been widely reported as marked by a substantial degree of syntactic fragmentation and unintegration (see section 2 for references).

\subsection{The purpose of the study}

I will argue below that the unintegration of relatives goes beyond the loss of inflection in co. It is observed in a range of other structural phenomena, also in który clauses, and these will be the focus of the discussion. More specifically, the first set of questions that will be addressed is: To what quantitative extent do który and co clauses display structural unintegration? Do który clauses - inherently better integrated than co clauses - display unintegration to a similar extent? The second set of questions is: What formal features of syntactic structure produce unintegration? Do co and który relatives share the same set of unintegration phenomena that could be jointly associated with unplanned speech?

Keeping these research questions in mind, the approach of the analysis is usage-based and aiming at enriching our knowledge of how canonical syntactic structures of written language or prescribed usage may differ from those observed in spontaneous speech. Analysis of the syntax of spontaneous spoken Polish has so far been very limited. Previous studies of the syntax of relativization in Polish are typically based on introspective data which include regular, integrated relative clauses (e.g. Bondaruk 1995; Mykowiecka 2001; Citko 2004; Szczegielniak 2006; Łęska 2016). While the relevance of introspection is not denied here, the kind of non-canonical constructions/functions that are examined in this paper are difficult to access through introspection; consequently, 
some non-canonical uses of Polish relativizers may have gone unnoticed. Namely, as will be argued in section 9, the complementizer co serves functions other than that of a straightforward relativizer.

Relativization in Slavic has also been studied largely on the basis of introspective and/or integrated data (e.g. Broihier 1995; Lavine 2003; Bošković 2009). Analyses focusing on authentic or non-standard relatives include Lapteva's (1976) analysis of conversational Russian, Murelli's (2001) analysis of non-standard relativization in European languages (unintegration is not one of the parameters analyzed), Hladnik's (2015) corpus-based study of Slovenian alternative relativization constructions, and Fried's (2010) and (2011) corpusbased analyses of Czech co and který relative clauses. However, none of these studies are immediately concerned with unintegration in relative clauses. This paper seeks to contribute to previous research into Polish and Slavic relativization by looking into unintegrated relatives in conversational Polish.

The central insight of the present study is that in conversational Polish there are a number of phenomena or features of non-canonical syntax producing structural unintegration in co and który relative constructions. This finding accords with previous analyses of unplanned speech (sections 1.1 and 2). The following unintegration features are found and discussed:

i) Gapless clauses as relative clauses (both co and który clauses) (section 4).

ii) Lack of required resumptive pronouns (in co clauses) (section 5).

iii) Non-canonical resumption (both co and który clauses) (section 6).

iv) Long-distance relationship with the head; marked word order (both co and który clauses) (section 7).

v) Preposition dropping (in co clauses) (section 8).

vi) Cline of functions; semantic ambiguity; lack of a nominal head (in $c o$ clauses) (section 9).

vii) Non-standard or mismatched inflection on the relative pronoun (in który clauses) (section 10).

The article is organized as follows. Section 2 reviews the literature on unintegrated relatives; section 3 introduces the Spokes corpus, the data selection criteria and data retrieval; sections 4-10 discuss particular unintegration features in co and który clauses; section 11 covers the quantitative findings; section 12 presents the conclusions.

\section{Previous literature on unintegrated relatives}

Fragmented and unintegrated syntax is a major feature distinguishing unplanned speech from written language (e.g. Chafe 1982; Greenbaum and Nelson 1995; Miller and Weinert 1998; Biber et al. 1999: 1140-1144, 1068-1070; Miller 2006; Miller and Fernandez-Vest 2006; Quaglio and Biber 2006). Miller 
(2011: 22) argues that "the assignment of syntactic structure to spontaneous speech is far from straightforward." Clauses are often combined into clause complexes rather than classical sentences, i.e. they are simply juxtaposed in information blocks which are interrelated but the structure of these complexes is less clear and less hierarchical than that of written sentences. For instance, subordination is often replaced by simple juxtaposition or parataxis.

This has been shown to be the case cross-linguistically. For example, Miller and Weinert (1998) and Miller (2011) find unintegration and fragmentation in spoken English, German and Russian, Sornicola (1981) in Italian, Zemskaja (1973) in Russian. With specific reference to relative clauses, Lapteva (1976) finds unintegration in Russian, Deulofeu (1981) in French, Miller and Weinert (1998) in English, German, and Russian, and Fiorentino (2007) in Italian. Below, we review the key points made by Miller and Weinert (1998) and Miller (2011), who make insightful comments about English that and which. As will be shown, the Polish data fit many of their observations.

Miller and Weinert (1998: 104-111) and Miller (2011: 26-29, 181-183) argue that in spontaneous spoken English which can be used in unintegrated relative structures in which it is associated with an antecedent NP but without the expected gap in the which clause - instead, the which clause is a complete gapless clause, as in (8). The entire complex is not bound together by the tight structural network typical of classic $w$ h-relative clauses.

(8) You have a little keypad down here which you can use your mouse to click on the keys. (Miller 2011: 28)

This use of which in (8) is paralleled by the similarly unintegrated that relative in (9):

(9) a filing cabinet that you can only open one drawer at a time. (Miller 2011:28)

Although which in examples such as (8) may be seen as a relative pronoun, Miller and Weinert (1998: 110-111) and Miller (2011:29) suggest that it might be better treated as a general conjunction or discourse connective linking chunks of discourse in a way similar to the conjunction $a$ and.

Based on such examples, Miller (2011: 183) argues that both that and which diachronically developed from pronouns to conjunctions, with which still retaining its parallel pronominal use, and that losing all of its pronominal features along the way. ${ }^{2}$ In the same vein, other authors (see section 9 for references) note that in a cross-linguistic historical perspective pronouns are often grammaticalized and develop relativizer, complementizer, and conjunctionlike functions.

2 That is also a complementizer in complement clauses (the assumption that the plan will fail), thus further extending the repertoir of its funtions. 
This paper shows that Polish uninflected co also seems to be a case of such diachronic change leading to synchronic polyfunctionality (from pronoun to relativizer to conjunction), as illustrated in section 9. The pronoun który, while retaining its pronominal status, is also found in loosely integrated relative constructions, although not to an extent which might indicate an expansion towards conjunction-like uses (see section 11 for quantitative information).

\section{Corpus and data}

The data in this paper come from Spokes (Pęzik 2015) - a corpus of conversational spoken Polish consisting of over 2 million words. Much of the corpus's transcribed material is aligned with audio data and it is only this section of the corpus that was used in the present study. The reason for this is that the audio material was used to verify that the transcripts are accurate and that only relevant tokens of co and który clauses were taken into account. In sum, approximately $77 \%$ of the corpus data were used, which translates into approximately 1.6 million words.

A sample of data was collected from Spokes by an exhaustive search of all occurrences of the words co and któr-y/-a/-e/etc. Each occurrence was manually inspected so that only relevant tokens were collected. ${ }^{3}$ Included in the sample were subject and object relative clauses (direct and oblique), both canonical (integrated) and non-canonical (unintegrated), as well as other related uses of co bordering on the relativizing function (section 9).

A methodological remark is due here. Although the study is based primarily on corpus data, certain points need to be illustrated with constructed examples or modified versions of Spokes data. This is necessary, for example, when we contrast corpus-derived unintegrated relatives with their constructed integrated counterparts. In such cases, the author's native speaker competence is used to provide the required examples. The three types of examples are marked accordingly 'Spokes', 'constructed' and 'modified. Original spelling and punctuation is preserved.

The discussion to follow addresses the unintegration features listed at the end of section 1.3.

3 The elimination process excluded utterances which proved irrelevant upon inspection of the audio. This included analysis of prosodic features to eliminate false starts, reformulations, self-repairs, chunks of language without syntactic connection (e.g. separate conversational turns). 


\section{Gapless clauses as relative clauses (both co and który clauses)}

This section addresses the first unintegration feature, which is that the relative clause may be a complete clause without a gap normally expected in relatives. This results in looser connectivity in the bipartite relative structure. Also, the relationship of the relative clause with the head NP may not be easily captured with syntactic descriptors such as subject or direct/oblique object. The syntactic and logical relationship is often idiosyncratic and needs to be inferred from the context. Consider example (10).

(10) (Spokes)

że się dogadają 0 tych $\mid$ o tym terminie co nie that REFL work.out-3PL-FUT about these about this deadline co not przysyła jej tych alimentów bo on mówi słuchaj może do he sends her these alimony because hesays listen maybe to tego komornika nie idź jakoś się dogadamy this debt collector not go somehow REFL work.out-1PL-FUT 'that they can work it out with those, with this deadline that he doesn't send her the alimony, because he says, listen, perhaps you shouldn't go to this debt collector, we can work it out'

Whereas standard co clauses have clearly defined nominal heads acting as subjects or direct objects of the relative-internal verbs (e.g. in (7): sukienke 'dress' - kupiłaś 'bought-2sG'), the relativized NP in (10) - i.e. tym terminie 'this deadline'- is only loosely tied syntactically to the co clause, and their relationship cannot be stated in the same object-verb terms as in examples (6-7). The relativized NP is not a core argument of the verb przesyla 'sends'; also, the co clause contains no gap for which the head would fill in - as would be expected in prototypical relative clauses. As a result, the co clause is a loosely connected referential expression specifying the head in more detail and paraphrasable to 'the deadline that he doesn't keep for sending her the alimony'.

Interestingly, although który clauses are inherently more integrated, the spoken medium still seems to impose a degree of unintegration in examples such as (11).

(11) (Spokes)

$\begin{array}{llllll}\text { no grupa to moim } & \text { zdaniem } & \mathrm{z} \text { definicji tacy } \\ \text { well group is } & \text { my } & \text { opinion } & \text { from definition such-MASC-NOM-PL } \\ \text { którzy } & & \text { jedna } & \text { osoba } & \text { placi za ileś } \\ \text { who-MASC-NOM-PL } & \text { one } & \text { person } & \text { pays for a number }\end{array}$

'Well, in my opinion, a group is by definition such people who one person pays for a number of people' 
The relative pronoun is appropriately inflected for number and gender to agree with the same features of its head (tacy 'such-MASC-PL', którzy 'whoMASC-PL'). Otherwise, however, example (11) is not a standard relative. The head tacy is not a core argument of the relative-internal verb płaci 'pay-3sG', even though the inflection of którzy would suggest a subject or direct object function. Note also that the relative clause has its own internal arguments and no gap. The entire clause complex is more loosely connected than is the case in a canonical który clause. In a standard well-integrated który clause, example (11) might be paraphrased as (12):

(12) (modified)

$\begin{array}{lllll}\text { grupa to tacy, } & \text { spośród } & \text { których } & \text { jedna } \\ \text { group is such-MASC-NOM-PL } & \text { from among } & \text { who-MASC-GEN-PL } & \text { one } \\ \text { osoba płaci } & & \\ \text { person pays } & & \\ \text { 'a group is such people from among whom one person pays' }\end{array}$

Consider example (13), which illustrates another aspect of loose integration with gapless clauses.

(13) (Spokes)

$\begin{array}{llrrrrr}\text { jak } & \text { zobaczyłam } & \text { tę } & \text { biżuterię } & \text { to } & \text { mało } & \text { że rosyjska } \\ \text { when } & \text { I saw } & \text { this } & \text { jewellery-F-SG } & \text { then } & \text { not only } & \text { that Russian } \\ \text { która } & \text { słynęła } & & \text { w ogóle } & \text { Rosja } & \text { Z } & \text { biżuterii } \\ \text { which-F-SG } & \text { was famous-F-SG } & \text { really } & \text { Russia } & \text { with } & \text { jewellery } \\ \text { 'When I saw this jewellery, not only was it Russian, which was really famous for } \\ \text { jewellery, Russia was' }\end{array}$

In (13), the relative-internal verb (stynęła 'was famous-F') has an ambiguous dual subject-verb connection to two NPs around it. The speaker starts off with rosyjska (bizuteria) 'Russian-F (jewellery)' as the head of the relative but ends up incorporating another NP as a second alternative subject of the verb. In effect, the relative clause która slynęła 'which was famous-F' connects back to bizuteria 'jewellery' and simultaneously throws a link forward to Rosja 'Russia. As both NPs are feminine, both are co-indexed with the feminine-inflected wh-pronoun and verb in która słynęła 'which was famous-F.' Thus example (13) has a non-canonical relative structure, in which - instead of the expected gap - an alternative subject NP is provided.

Example (14) with the complementizer co features a similar dual backwardand-forward connection. 
(14) (Spokes)

$\begin{array}{lllllllll}\text { nie no to jest ta choroba } & \text { co } & \text { ojciec ma co ty tez } \\ \text { no well this is this disease } & \text { co } & \text { father has co you also } \\ \text { nie chcesz brać te } y & \text { plasterki } & \text { co } & \text { on nalepia } & & \\ \text { not want take these plasters-Nom } & \text { co he sticks } & \end{array}$

'no, this is the disease that father has, which you also don't want to take, those plasters that he sticks on'

In (14), the verb brać 'to take' seems to link back to the NP ta choroba 'this disease' as the head of the relative, but at the same time the NP does not make sense as the object of the verb ('disease - take'). Instead, the verb throws a link forward to the head of the following co clause, i.e. te plasterki 'these plasters' in that te plasterki seems to be the object of brać. Additionally, the object NP te plasterki is accusative rather than genitive, as would be expected through the genitive of negation, thus undermining the integrity of the entire utterance even more (see section 10 for discussion of accusative forms replacing the genitive).

To sum up this section, examples (10), (11), (13) and (14) illustrate the absence of the gap normally expected in relative clauses. Instead, complete gapless clauses are found, which results in looser integration. Additionally, these gapless clause complexes may even display ambiguity as to which NP acts as the subject (in (13)) or object (in (14)).

\section{Lack of required resumptive pronouns (in co clauses)}

In this section, I argue that the absence of resumptive pronouns may undermine the integration of a co relative clause, especially when their presence would be expected in a given grammatical configuration. Additionally, when resumptives are absent, integration is markedly lower when the case form of the head does not match the case form of the trace.

As is well-known, resumption is used in object co relative clauses, but not in subject clauses. However, even among objects, resumption is optional, indeed rare in some contexts, preferred in others, and required in still others. The connectivity of co clauses is loosened when the preferred/required resumptives are missing in unplanned speech. In short, the contextual factors favouring resumption include (i) animate antecedents (especially humans), (ii) non-accusative objects (regardless of animacy), and (iii) non-matching (non-identical or non-syncretic) case forms between the head and the object of the relative clause (cf. Hladnik 2015). In these contexts, resumptives are required (examples (15) and (16)), ${ }^{4}$ or at least they produce more felicitous results, as in (17):

4 The asterisk outside the bracket indicates that the relative is fine with the resumptive, but unacceptable without it. 


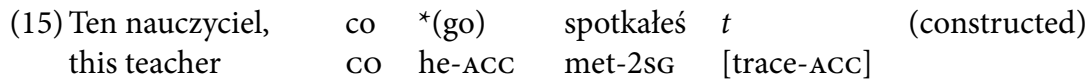
'This teacher you met'

(16) To pióro co ${ }^{*}(\mathrm{nim})$ pisałam $t \quad$ (constructed) this pen-NOM CO he-INSTR wrote-1sg [trace-INSTR] 'the pen I wrote with'

(17) Ta sukienka, co ? (jej) nie założyłam $t \quad$ (constructed) this dress-NOM CO she-GEN not put.on-1sG [trace-GEN] 'This dress I didn't put on'

In (17) there is a case-matching effect whereby the combination of the nominative antecedent and the genitive trace is awkward and less integrated without the resumptive, compared to the modified case-matched version in (18).
$\begin{array}{cllll}\text { (18) Tej sukienki, } & \text { co } & \text { nie założyłam } & t & \text { (constructed) } \\ \text { this dress-GEN } & \text { co } & \text { not put.on-1sG } & \text { [trace-GEN] } & \end{array}$ 'This dress I didn't put on'

Note that identical or syncretic case forms are particularly suitable to coconstruct a co relative clause. Consider (19) from Spokes and (20), which is based on (19). The nominative head in (19) is syncretic with its accusative trace and therefore the construction is well-integrated. In contrast, (20) is slightly unintegrated in the version with the nominative head $t a$ because it is not syncretic with the accusative trace. The sentence improves with the accusative-inflected head tę.
(19) $\mathrm{Te}$
co miałam $t$
na sylwestra
(Spokes)
these-NOM/ACC CO I had [trace-ACC] on New Year's Eve
'the ones I had on for the New Year's Eve party'
(20) ?Ta $/$ tę co miałam $t$ na sylwestra (modified) this-NOM /this-ACC CO I had [trace-ACC] on New Year's Eve 'the one I had on for the New Year's Eve party'

Some co relatives found in Spokes do not adhere to the ideal case-matched configuration. Example (21) from Spokes sounds better integrated in its rephrased version in (22), where the resumptive mediates an agreement between the case of the head and the case of the trace, and in (23), where the case of the head has been adjusted to match that of the trace.
(21) to jest ta
co przywiozłam $t$ ?
it is this-NOM CO I brought [trace-ACC]
(Spokes, low integration)
'Is it the one I brought?' 
(22) to jest ta co ją przywiozłam $t$ ? (modified, better integration) it is this-NOM co she-ACC I brought [trace-ACC]

'Is it the one I brought?'

(23) masz gdzieś tę co przywiozłam $t$ ? (modified, better integration) you have somewhere this-ACC-F Co I brought [trace-ACC]

'Have you got the one I brought somewhere here?'

Lack of resumption is observed also in relatives with oblique traces, as in (24) and (25), where the awkwardness is even more easily perceived than with accusative traces. The sentences improve greatly with the inclusion of genitiveinflected resumptives (absent in Spokes and added here in parentheses).

(24) może rozbrajaj najpierw te co [ich] nie widać $t$ (Spokes) maybe disarm first these-ACC CO [they-GEN] not be seen [trace-GEN] 'maybe you should first disarm the ones that cannot be seen'

\begin{tabular}{|c|c|c|c|c|}
\hline (25) tamte & co & [ich] & używałaś & $t$ \\
\hline
\end{tabular}

\section{Non-canonical resumption (both co and który clauses)}

In spontaneous speech, non-canonical relative clauses exhibit resumption that may appear excessive or redundant. Thus, in contrast to the preceding section, resumption can also undermine integration. Given that unintegration is common in unplanned speech, resumptives allow precisely this kind of organisation of discourse, i.e. one of loosely connected strings, with resumptives providing explicit reference, for example when the identity of a gapped argument would have been unclear. This will be shown below.

Resumption is associated with complementizer relative clauses and expected especially in specific configurations (see section 6). Wh-pronoun relative clauses do not normally trigger resumption. However, in spontaneous speech, anaphoric items may be used even in $w h$-relatives when the reference of a gapped argument would be unclear. This may be the case when the head and the relative clause are separated with intervening material. In such cases, resumption is a strategy of recovering the referent of the head, cf. (26) and (27). In (26), the head (te generyczne 'these generic ones') is resumed in the anaphoric je 'them', which is the object of the relative-internal verb (produkuja 'produce-3PL'). In (27), the resumptive on is the subject of the relative-internal verb $z$ dawat 'took-3sG'. 
(26) (Spokes)

jest szereg leków które można spokojnie podawać

is number medicines which one may safely administer

wiesz troszeczkę tańsze polskie odpowiedniki to są te

you know a little cheaper Polish replacements it are these

wiesz generyczne które tam jeszcze $u$ nas ta ochrona

you know generic which there yet at us this protection

patentowa nie działa tak dobrze $\mathrm{i}$ je produkują.

patent notworks so well and them produce-3PL

'There's a range of drugs that you can safely administer, you know, a little cheaper Polish replacements, they are, you know, those generic ones which our patent protection laws don't work so well and they produce them'

(27) (Spokes)

mieliśmy kolegę który też dwa lata temu jak my zaczynaliśmy had-1PL friend who also two years ago when we were starting prace to on zdawal egzamin work then he took exam

'We had a friend who also two years ago when we were starting work he took the exam'

In (28) below, there is an embedded clause (cała Łódź mówi 'the whole Łódź says'), and in its complement clause (że taki dobry chleb $z$ tej piekarni jest 'that the bread from this bakery is so good'), a resumptive nominal is used to clarify the referent of the head NP. As a result, the head NP chleb 'bread' is repeated and the integration of the relative is undermined. Further, the prepositional complement $z$ tej/takiej piekarni 'from this bakery' is also resumed, which intensifies the effect of separation of the two parts of the sentence. Resumption replaces the canonical structure with gapped sentence constituents. In doing so, który is similar to co. In a canonical integrated version, a piedpiped preposition might be used instead of resumption, as in (29).

(28) (Spokes)

$\begin{array}{lllllll}\text { z } & \text { takiej } & \text { piekarni } & \text { przyniosłem chleb który cała tódź mówi } \\ \text { from } & \text { such } & \text { bakery } & \text { brought-1sG bread } & \text { which whole Łódź says } \\ \text { że } & \text { taki } & \text { dobry chleb } \mathrm{z} & \text { tej piekarni jest! } & \\ \text { that } & \text { such } & \text { good } & \text { bread from this bakery is } & \end{array}$

'In this bakery I got bread that the whole Łódź says it's such good bread from this bakery'

(29) (modified)

z takiej piekarni przyniosłem chleb, o którym cała Łódź from such bakery brought-1sG bread about which whole Łódź mówi, że jest taki dobry! says that is so good

'In this bakery I got bread about which the whole Łódź says that it's so good' 
Analogically, resumptives are also observed in co clauses where speakers resume the head in unintegrated clauses, as in (30), where jakieś [...] robaki 'some bugs' is resumed in the diminutive te robaczki 'these bugs-DIM'.

(30) (Spokes)

$\begin{array}{llllll}\text { jakieś } & \text { mi się robaki } & \text { wdały } & \text { nie wiem } & \text { co tak skakały } \\ \text { some } & \text { me } & \text { REFL bugs } & \text { came.round-3PL I don't know } & \text { co so jumped-3PL } \\ \text { te } & \text { robaczki } & \text { po tych listkach } & & \end{array}$
'some bugs came round, I don't know, that jumped about these little bugs all over the leaves'

Although resumption seems justified where the relative clause is substantially removed from the head, the separation is not always the trigger of resumption. Consider the który relative in (31), in which tacy 'those-NOM' is resumed in im 'they-DAT'. As a result, the który clause is a gapless one. A classic integrated który relative would have a dative-inflected relative pronoun and no resumption. ${ }^{5}$

(31) (Spokes)

są tacy którzy właśnie nie podoba im się to za bardzo are such-NOM who-NOM precisely not like they-DAT REFL it too much

'There are those who they don't like it too much'

\section{Long-distance relationship with the head; marked word order (both co and który clauses)}

Another unintegration feature is that both co and który clauses can be dislocated from the typical head-adjacent position, and appear later in the discourse, thus separating the two elements of the construction (without resumption) and producing unintegration. For example, in (32), the head and the co clause appear in different conversational turns, the co clause in bold linking back to to zdjęcie $z$ Madrytu 'this photo from Madrid'.

(32) (Spokes)

A: pamiętasz to zdjęcie $z$ Madrytu takie mamy co tak remember-2sg this photo from Madrid such have-2PL co so sobie siedzimy

REFL sitting-2PL

${ }^{5}$ To comment on the use of dative-inflected relative pronouns, Miller and Fernandez-Vest (2006: 50) observe that whose and whom are a "hallmark of formal written English" and are "absent from most spontaneous spoken English." Instead, unintegrated relatives are common in unplanned speech (e.g. would those men I call their names step forward). 
$\begin{array}{cllll}\text { B: } z & \text { Madrytu } & \text { czy } & \mathrm{z} & \text { Wiednia? } \\ \text { from } & \text { Madrid } & \text { or } & \text { from } & \text { Vienna }\end{array}$

$\begin{array}{llllll}\text { A: nie } & \mathrm{z} & \text { Madrytu } & \text { co } & \text { siedzimy wcinamy kanapeczki }\end{array}$

no from Madrid CO sitting-1PL eating-1PL sandwiches

'Remember this photo from Madrid that we have, that/where we're just sitting'

'From Madrid or from Vienna?'

'No, from Madrid, that/where we're sitting, eating sandwiches'

In (33), the który clause - although it seems to be a restrictive relative - is structurally and prosodically separated from its head by a parenthetical question in between.

(33) (Spokes)

mieliście jakieś meldunki chyba tutaj one były na Legionów tak? had-2PL some registrations probably here they were on Legionów yes których się nie dało wymeldować which REFL not be possible check out

'Apparently you had resident registrations, over here in Legionów Street, right? which you could not check out'

In (34), the non-canonical word order separates the head and the który clause with the main clause verb (cf. the standard word order of 'head+relative clause+main verb' in jakieś tam normy których przestrzegaja musza być chyba 'some norms which they adhere to must exist, presumably'). The same word order is used in the co clause in (35), where the relative clause falls outside the main interrogative clause both prosodically and in terms of word order. The marked word order of (34) and (35) represents another type of loosening of the ties between the head and the relative clause in spontaneous speech.

(34) (Spokes)

jakieś tam normy muszą być chyba których przestrzegają some there norms must be presumably which adhere.to-3PL

'Some norms must exist, presumably, which they adhere to'

(35) (Spokes)

$\begin{array}{llllllll}\text { A co } & \text { się } & \mathrm{Z} & \text { tym } & \text { zapasowym } & \text { pokojem } & \text { stało? } \\ \text { and } & \text { what } & \text { REFL } & \text { with } & \text { this } & \text { spare } & \text { room } & \text { happened }\end{array}$ co był taki zapasowy 205 czy coś

co was such spare 205 or something

'What happened to this spare room? that we had this spare one, 205 or something'

\section{Preposition dropping (in co clauses)}

In this section, the ellipsis of prepositions (and of accompanying resumptive pronouns) is shown to be another feature weakening the integration of $c o$ 
relative clauses. This is contrasted with the obligatory pied-piped prepositions in który clauses.

Miller and Weinert (1998: 105-110) note that in spontaneous spoken English the prepositions are frequently omitted in relative clauses, as in (36) and (37), where the reconstructed prepositions are in parentheses:

(36) of course there's a rope that you can pull the seat back up [with]

(37) I haven't been to a party yet that I haven't got home [from] the same night

Similarly, the omission of prepositions is observed in Polish co relative clauses. Additionally, along with the preposition, a resumptive pronoun referring to the relativized head is omitted, as it has no preposition to complement. In (38) and (39) the reconstructed prepositions and resumptive pronouns (absent in Spokes) are inserted in parentheses.

(38) (Spokes)

z tym chłopakiem mieszkałaś coteraz $\left[\begin{array}{ll}z & \text { nim }\end{array}\right]$ mieszkasz? with this boy lived-2sg co now [with him] live-2sG

'You were living with this boy that you're now living [with]?'

(39) (Spokes)

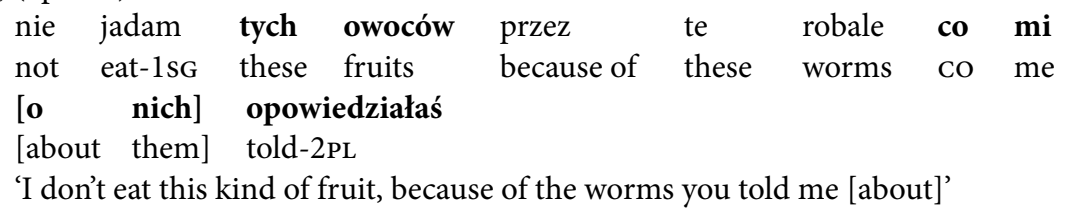

Note that corresponding który relatives with preposition ellipsis are unacceptable, pied-piped prepositions being obligatory with the wh-pronoun, cf. (40).

(40) (modified)

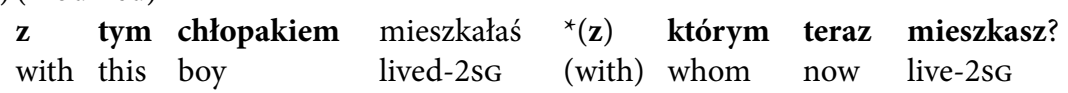

'You were living with this boy ${ }^{\star}$ (with) whom you're now living?'

The availability of preposition dropping in co clauses, but not in który clauses, is related to the distinct statuses of the two relativizers. Co, as a complementizer, indicates a subordination link between the head and the relative clause without a gap. This connection is looser, gapless, and linear. The preposition is not pied-piped but (optionally) linked to the resumptive (which is expressed only if the preposition is overtly expressed), and the presence of the preposition introducing the head ( $z$ tym chlopakiem 'with this boy') is enough to recover the same preposition dropped in the co clause. On the other hand, 
pied-piping is the only option for wh-pronouns. In (40), the instrumental-inflected $k$ tóry- $m$ co-occurs with a resumed pied-piped preposition which must be overtly expressed ( $\boldsymbol{z}$ tym chłopakiem, $\boldsymbol{z}$ którym...). Thus, the wh-pronoun relative clause is a tighter structure with a denser network of agreement features, in which preposition dropping is not available.

\section{Cline of functions; semantic ambiguity; lack of a nominal head (in co clauses)}

This section focuses on the semantic ambiguity of some co clauses, which is a result of an ambiguous semantic contribution of $c o$ itself. Underpinning the discussion is the observation that in a cross-linguistic historical perspective pronouns are often grammaticalized and develop other functions: relativizers, complementizers, conjunction-like uses (Citko 2004: 107; Miller 2011: 183; Minlos 2012; Hansen et al. 2016: 205-206; Kehayov and Boye 2016: 860). This is the case with English that and which (see discussion in section 2) and Croatian čim 'when' reported by Minlos (2012: 75).

Co may serve several functions and in some cases it is difficult to say which reading is to be applied. Specifically, co may be construed as: (1) a complementizer, (2) a time-reference conjunction similar to English when, or (3) a placereference conjunction similar to English where. However, in still other cases, co may ambiguously represent all these three functions, thus blurring the contrast between relativizing, spatial, and temporal uses of $c o$.

In colloquial Polish there is a time-reference expression - wtedy, co 'when' (literally 'then that'), illustrated in (41) - which in colloquial style is often ellipted to $c o$, as in (42).

(41) (Spokes)

to wygląda prawie jak my startowaliśmy na Materhorn wtedy co this looks almost like we set.off-1PL on Matterhorn then co czekaliśmy na okazję przy tej waited-1PL on ride at this 'this looks almost like when we set off for the Matterhorn, when we tried to hitch a ride at the'

(42) (Spokes)

A: w Sylwestra to było?

in New Year's Eve it was

B: no tak to musiało być $w$ Sylwestra bo to było $\mathrm{w}$ well yes it must-PAst be in New Year's Eve because it was in nowy rok co myśmy na tych tych zjeżdżali New Year's Day co AUX on these these went.sledding-1PL 
'Was that on New Year's Eve?'

'Well yes, it must have been the New Year's Eve, because it was on New Year's Day that we went sledding on those'

While co in example (42) may be seen as the ellipted (wtedy,) co, this is not clear at all; it may as well be treated as a general conjunction connecting two main clauses - in these examples with a shade of temporal meaning. In other examples, the same meaning of a temporal conjunction is detectable in co clauses following NPs which may be construed as relativized heads. In such cases it is hard to differentiate (wtedy,) co from co as a conjunction and from co as a relativizer in NPheaded relative clauses. The ambiguous function of $c o$ combined with the loose syntactic and semantic relationship between heads and co clauses means that the ambiguity is a fairly common occurrence. Consider examples (43-45).

(43) (Spokes)

to było wtedy jak jechałeś na tą imprezę do akademika

it was then how went-2sG on this party to dorm

co nie chciałeś Reni powiedzieć

CO not wanted-2sG Renia-DAT tell

'It was when you went to this party at the dorm that/when you didn't want to tell Renia'

(44) (Spokes)

teraz ja chciałam już żebyście mi przywieźli $\mathrm{w}$ tą niedzielę now I wanted already AUX-2PL me brought-2PL in this Sunday

co ostatnio byliście

co lately were-2PL

'Now I wanted you to bring (it) to me already on that Sunday that/when you were here the other day'

(45) (Spokes)

ciekawe jakbyśtak spadła $\mathrm{z}$ tego tego pontona co tak interesting supposing fell-2sG from this this inflatable boat Co so pływałaś jak byś ciekawe jak by to wyglądało no floated how AUX interesting how AUX it looked-3sg yes 'I wonder, if you'd fallen off that inflatable boat that/when you floated there, I wonder what that would look like'

In examples (43-45) the co clauses are used by speakers as time-reference devices reminiscent of the wtedy, co construction. At the same time, they seem to be linked to their respective head NPs in a way that resembles the structure of relative clauses, although with some features typical of spontaneous speech such as preposition dropping. ${ }^{6}$ Given the inherent loose integration of co clauses, the ambiguity is not to be easily resolved. This is shown in the op-

${ }^{6}$ Compare the reconstructed preposition and accompanying resumptive in: $z$ tego pontona co [na nim] tak plywataś 'off that inflatable boat that you floated [on]'. 
tional English glosses for co above in (43-45). The co clauses can be interpreted as temporal when-clauses (paraphrasable with wtedy, co) or unintegrated relative clauses modifying head nouns. On the first reading $c o$ is a connective element akin to a conjunction, on the second - a relativizing complementizer.

In other cases, co seems to perform the function of a place-reference conjunction similar to English where, as in (46), although the same example may also be seen as a relative clause introduced by a complementizer and with preposition dropping (cf. $w$ tym sklepie co $[$ w nim] sq...).

(46) (Spokes)

i w tym drugim sklepie co są $z$ kolei te frotki i dzianinki and in this second shop co are in turn these hair ties and fabrics

'And in this other shop where/that they have hair ties and fabrics'

In other cases there does not appear to be a head associated with the co clause, thus making a relative clause reading untenable in favour of a place-reference conjunction reading. The co clause is a loosely structured headless comment intended to help identify the location of a place. In such uses, co may be paraphrased with the correlative complex tam, gdzie 'where' (lit. 'there where'), as in (47) and (48).

(47) (Spokes)

a to tutaj mieszkają| co mają| co taka cysterna stoi? oh it here live-3pl co have-3PL co such cistern truck stands 'Oh, so they live where, where they have, where the cistern truck is?'

(48) (Spokes)

A: Kaweckiten | wnuk ten tej | wiesz który Kawecki this grandson this-NOM-M this-GEN-F know-2sg which

B: no yeah

A: przed mechanikiem | przed Borowcem co ten dom jest pobudowany next to garage next to Borowiec co this house is built

'This Kawecki guy, the grandson of what's-her-name, you know who'

'Yeah'

'Next to the garage, next to the Borowiec place, where this house has been built'

All in all, examples (42-48) illustrate a cline of uses of co ranging from a straightforward complementizer, through ambiguous temporal-relativizing and locative-relativizing uses, to a time- and place-reference conjunction. The existence of this cline of function fits well the observation that in a diachronic perspective pronouns often develop other complementizer and conjunctionlike functions often with an intermediate relativizer stage. Polish uninflected co also seems to be a case of such diachronic change leading to synchronic polyfunctionality (from pronoun to relativizer to conjunction). 


\section{Non-standard or mismatched inflection on the relative pronoun (in który clauses)}

In spontaneous speech the structural integration of który clauses may be compromised through the use of non-standard/mismatched inflections on the whpronoun. It is difficult to say to what extent these inflections are mere performance disfluencies. At least in some cases, there seem to be patterns which point to broader tendencies rather than just one-off phenomena. One such example is the genitive of negation, whereby accusative objects change into genitive objects in negatives, cf. (49) and (50).
(49) Ten artykuł, który czytałeś (constructed) this article which-ACC-SG read-2sG 'This article which you read'
(50) Ten artykuł, którego / *który nie czytałeś (constructed) this article which-GEN-SG which-ACC-SG not read-2sG 'This article which you didn't read'

Willis (2013: 361) reports a slight shift towards use of the accusative in modern Polish, especially in contexts of long-distance genitive of negation (also Przepiórkowski 2000), while admitting that it is not clear whether this is due to systematic language change. The non-application of genitive of negation in long-distance cases is illustrated in (51), found in an on-line news service.

(51) (Internet)

$\begin{array}{llllll}\text { TVP nie } & \text { uważała } & \text { za stosowne } & \text { dać } & \text { transmisję } & z \\ \text { TVP not considered } & \text { as appropriate } & \text { to give } & \text { transmission-ACC } & \text { from } \\ \text { uroczystości } & & & & & \\ \text { celebration } & & & & & \end{array}$

'TVP didn't consider it appropriate to broadcast the celebration'

Thus the genitive-accusative alternation does not seem to have a clear-cut distribution. Aside from long-distance cases, Ilc (2011) observes that in Slovene the genitive of negation, which is otherwise obligatory in standard language, is often replaced by the accusative in colloquial style. The same may be the case in colloquial modern Polish in that the canonical genitive is occasionally replaced by accusative forms, as in (52).

(52) (Spokes)

najlepsze są te które on nie robił

best are those which-ACC-PL he not did

'The best are those which he didn't do' 
Also, the genitive may be replaced by the accusative outside the genitive of negation construction. Consider the mismatch between the use of the accusative relative pronoun and the genitive trace in (53), the mismatch being in part due to the growing tendency for the verb $u \dot{z} y w a c$ to be used with accusative objects instead of the canonical genitive.

(53) (Spokes)

\{ja mam wszystkie plastikowe sitka to znaczy\}

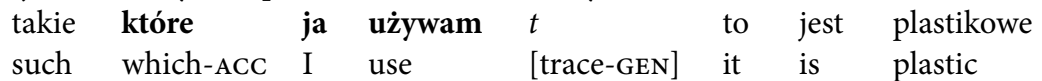

'All my sieves are plastic, I mean the one I use is plastic'

The genitive may also be used where the accusative would otherwise be expected in standard language, as in (54). Here the mismatch reflects the common confusion of two masculine declensions - masculine animate and masculine inanimate - the former having syncretic genitive and accusative forms, the latter displaying contrast in the two cases.

(54) (Spokes)

\{mam egzamin zaległy jeszcze z zeszłego roku\}

$\begin{array}{lllll}\text { którego } & \text { muszę } & \text { zdać } & t & \text { teraz } \\ \text { which-GEN } & \text { have.to-1sG } & \text { pass } & \text { [trace-ACC] } & \text { now }\end{array}$

'I have an outstanding exam from last year which I have to pass now'

Above we have noted the mutual replacement of the accusative and the genitive relative pronoun forms. Regardless of whether Polish is undergoing a systematic change in this respect - as indicated in the literature in reference to the genitive of negation - the accusative/genitive mismatch is another factor that compromises the syntactic cohesion of który relative clauses.

\section{Quantitative information}

This section summarizes the quantitative findings on the unintegration features in co and który relative clauses retrieved from Spokes. As can be seen in Table 1, który clauses display unintegration features with a frequency rate of $4.5 \%$ and both subject and object relatives contribute to this rate almost equally ( $4.7 \%$ and $4.2 \%$ respectively).

Table 1: (Un)integration of który clauses in Spokes

\begin{tabular}{|l|r|r|r|}
\hline & \multicolumn{1}{|c|}{ Integrated } & \multicolumn{1}{c|}{ Unintegrated } & \multicolumn{1}{c|}{ Total } \\
\hline Subject który relative clauses & $1,235(95.2 \%)$ & $61(4.7 \%)$ & $1,296(100 \%)$ \\
\hline Object który relative clauses & $723(95.6 \%)$ & $32(4.2 \%)$ & $755(100 \%)$ \\
\hline Total & $1,958(95.4 \%)$ & $93(4.5 \%)$ & $2,051(100 \%)$ \\
\hline
\end{tabular}


Table 2 represents the more varied situation in co clauses. Namely, altogether, co clauses display the unintegration features discussed in this paper much more frequently than który clauses, as shown in the $32 \%$ rate of occurrence. However, there is an important quantitative difference between subject $c o$ clauses and non-subject $c o$ clauses (the latter including object relative clauses and clauses introduced by $c o$ as a conjunction or discourse connective). While subjects exhibit unintegration in $13.5 \%$ of cases, the unintegration features are observed in non-subjects with the frequency of 52.6\%. Recall that it is often difficult to distinguish relativizing uses of $c o$ from its conjunction-like uses (section 9) because the cline of functions it serves leads to interpretational ambiguity; therefore, all non-subject co clauses are included in this umbrella category.

Table 2: (Un)integration of co clauses in Spokes

\begin{tabular}{|l|r|r|c|}
\hline & \multicolumn{1}{|c|}{ Integrated } & Unintegrated & Total \\
\hline Subject co relative clauses & $365(86.4 \%)$ & $57(13.5 \%)$ & $422(100 \%)$ \\
\hline $\begin{array}{l}\text { Non-subject co relative } \\
\text { clauses }\end{array}$ & $\begin{array}{r}180 \text { object relatives } \\
(47.3 \%)\end{array}$ & $\begin{array}{r}200 \text { object relatives } \\
\text { and conjunction-like } \\
\text { uses (52.6\%) }\end{array}$ & $380(100 \%)$ \\
\hline Total & $545(67.9 \%)$ & $257(32 \%)$ & $802(100 \%)$ \\
\hline
\end{tabular}

Based on the information in Tables 1 and 2, we draw the conclusion that $c o$ clauses are much more likely than który clauses to have looser structural integration due to the occurrence of the unintegration phenomena discussed in this paper. While the probability is three times higher for subject co clauses, in the case of non-subject $c o$ clauses, the rate of occurrence of unintegration features is 12.5 times higher than that in który clauses. Much of this increase of unintegration is to be attributed to the indeterminate status of $c o$ as a relativizer or conjunction, with its cline of functions often inviting multiple/ambiguous readings.

\section{Conclusion}

Co clauses are inherently less integrated than który clauses for their lack of the network of agreement features. At the same time, both co and który clauses are subject to the constraints of real-time speech production, and spontaneous speech is known to be marked by unintegration, fragmentation, and parataxis, compared with the neat organisation of written language. It has been therefore the purpose of this paper to investigate the relative unintegration of these two types of clauses. In spontaneous conversational Polish, both co and który clauses display unintegration features that loosen the connectivity between the 
head and the relative clause. This is in line with what has been reported in the literature on unplanned speech (Miller and Weinert 1998). Some of these features are shared between co and który clauses, others are only observed in the former, but not the latter (see Table 3 below). Due to specific properties of the two types of clauses, certain features are only applicable to one, but not to the other. The distribution of the features is represented in Table 3.

Table 3: Distribution of unintegration features

\begin{tabular}{|l|c|c|}
\hline Unintegration feature & $\begin{array}{c}\text { który } \\
\text { clauses }\end{array}$ & $\begin{array}{c}c o \\
\text { clauses }\end{array}$ \\
\hline Gapless clauses as relative clauses & + & + \\
\hline Long-distance relationship with the head & + & + \\
\hline Marked word order & + & + \\
\hline Lack of required resumptive pronouns & $\mathrm{n} / \mathrm{a}$ & + \\
\hline Non-canonical resumption & + & + \\
\hline Preposition dropping & - & + \\
\hline Semantic ambiguity of the relative marker (cline of functions) & - & + \\
\hline Lack of a nominal head & - & + \\
\hline Non-standard or mismatched inflection of the relative pronoun & + & $\mathrm{n} / \mathrm{a}$ \\
\hline
\end{tabular}

Although there is a degree of overlap in the range of unintegration features in both types of relatives, there is a substantial difference in the quantitative extents to which co and który clauses display the above unintegration features. While subject co clauses exhibit the unintegration phenomena three times as frequently as który clauses, non-subject co clauses (including object relatives and clauses introduced by $c o$ as a conjunction or discourse connective) include the unintegration features 12.5 times as often as który clauses. Much of this increase of unintegration in non-subject co clauses is to be attributed to the indeterminate status of $c o$, with its cline of functions as a relativizing complementizer, general conjunction, or time- and place-reference conjunction, often inviting multiple/ambiguous readings. As argued in this paper, this polyfunctionality of $c o$ is a result of its diachronic development from pronoun to complementizer/relativizer and to conjunction. In contrast, który is essentially a wh-pronoun with relatively infrequent unintegration in który clauses, which may be attributed to the specificity of spontaneous speech rather than seen as an expansion in the pronoun's categorial status. 


\section{References}

Biber Douglas, Johansson Stig, Leech Geoffrey, Conrad Susan, Finegan Edward (1999). Longman Grammar of Spoken and Written English. Harlow: Pearson Education Limited.

BondARuK Anna (1995). Resumptive pronouns in English and Polish. In Licensing in Syntax and Phonology. PASE Studies and Monographs, vol. 1, Edmund Gussmann (ed.), 27-55. Lublin: Folium.

BošKović Željko (2009). On Relativization Strategies and Resumptive Pronouns. In Studies in Formal Slavic Phonology, Morphology, Syntax, Semantics and Information Structure. Proceedings of FDSL 7, Gerhild Zybatow, Uwe Junghanns, Denisa Lenertová, Petr Biskup (eds.), 79-92. Frankfurt: Peter Lang.

Boye Kasper, Kehayov Petar (eds.) (2016). Complementizer Semantics in European Languages [Empirical Approaches to Language Typology 57]. Berlin/Boston: Mouton de Gruyter.

Broinier Kevin (1995). Optimality-theoretic rankings with tied constraints. Slavic relatives, resumptive pronouns and learnability. MIT. PhD dissertation.

Callies Marcus (2012). The grammaticalization and pragmaticalization of cleft constructions in present-day English. In Corpus Linguistics: Looking Back - Moving Forward, Sebastian Hoffmann, Paul Rayson, Geoffrey Leech (eds.), 5-21. Amsterdam: Rodopi.

ChAfE Wallace (1982). Integration and involvement in speaking, writing, and oral literature. In Spoken and Written Language: Exploring Orality and Literacy, Deborah TAnnen (ed.), 35-53. Norwood, NJ: Ablex.

Сітко Barbara (2004). On headed, headless and light-headed relatives. Natural Language and Linguistic Theory 22(1), 95-126.

Deulofeu José (1981). Perspective linguistique et sociolinguistique dans létude des relatives en français. Recherches sur le Français Parlé 3, 135-194.

ENKVIST Nils Erik (1982). Imprompu speech, structure and process. In Impromptu Speech: A Symposium, Nils Erik Enkvist (ed.), 11-32, Åbo: Åbo Akademi Foundation.

Fiorentino Giuliana (2007). European relative clauses and the uniqueness of the relative pronoun type. Rivista di Linguistica 19(2), 263-291.

FrIED Mirjam (2010). Accusative resumptive pronoun in Czech relative clauses with absolutive relativizer co. Korpus, Gramatika, Axiologie 1(1), 16-29.

FrIED Mirjam (2011). Grammatical analysis and corpus evidence. In Grammar and Corpora 3, Marek Konopka, Jacqueline Kubczak, Christian MaIR, František ŠTíchA, Ulrich H. WAssner (eds.), 63-86. Mannheim: Narr Verlag.

Greenbaum Sidney, Nelson Gerald (1995). Clause relationships in spoken and written English. Functions of Language 2, 1-21.

Guz Wojciech (2015). The structural non-integration of wh-clefts. English Language and Linguistics 19(3), 477-503.

Hansen Bjorn, Letuchiya Alexander, BŁaszczyk Izabela (2016). Complementizers in Slavonic (Russian, Polish, and Bulgarian). In Boye, Kehayov (eds.), 175-223.

HLADNIK Marko (2015). Mind the gap. Resumption in Slavic relative clauses. Utrecht University. PhD dissertation. 
Hopper J. Paul, Thompson Sandra A. (2008). Projectibility and clause combining in interaction. In Crosslinguistic Studies of Clause Combining. The Multifunctionality of Conjunctions, Ritva Laury (ed.), 99-124. Amsterdam: John Benjamins.

ILC Gašper (2011). Optionality of the genitive (of negation) in Slovene. In Formalization of Grammar in Slavic Languages. Contributions of the Eighth International Conference on Formal Description of Slavic Languages - FDSL VIII 2009 University of Potsdam, December 2-5, 2009, Peter Kosta and Lilia Schürcks (eds.), 193-206. Frankfurt am Main: Peter Lang.

Kehayov Petar, Boye Kasper (2016). Complementizer semantics in European languages: overview and generalizations. In Boye, KeHAyov (eds.), 809-878.

Lavine James E. (2003). Resumption in Slavic. Phases, cyclicity and case. In Formal Approaches to Slavic Linguistics 11, Wayles Browne (ed.), 355-372. Ann Arbour Michigan Slavic Publications.

Lapteva Olga A. (1976). Russkij razgovornyj sintaksis. Moscow: Nauka.

ŁĘSKa Paulina (2016). Agreement under case matching in Polish co and który relative clauses headed by numerically quantified nouns. Journal of Slavic Linguistics 24(1), 113-136.

Miller Jim (2006). Spoken and written English. In The Handbook of English Linguistics, Bas AARTs and April McMahon (eds.), 670-691. Oxford: Blackwell.

Miller Jim (2011). A Critical Introduction to Syntax. London/New York: Continuum.

Miller Jim, Fernandez-Vest Jocelyne, J. (2006). Spoken and written language. In Pragmatic Organisation of Discourse in the Languages in Europe, Giuliano BERNINI and Maria L. Schwartz (eds.), 9-64. Berlin: Mouton de Gruyter.

Miller Jim, Weinert Regina (1998). Spontaneous Spoken Language. Syntax and Discourse. Oxford: Clarendon Press.

Minlos Philip (2012). Slavic relative čto/co: between pronouns and conjunctions. Slověne. International Journal of Slavic Studies 1(1), 74-91.

Murelli Adriano (2011). Relative Constructions in European Non-Standard Varieties [Empirical Approaches to Language Typology 50]. Berlin/New York: Mouton de Gruyter.

Mүкошіеска Agnieszka (2001). Polish relatives with the marker co. In Generative Linguistics in Poland. Proceedings of the GLiP-2 Conference, Adam Przepiórkowski and Piotr BAŃski (eds.), 149-57. Warszawa: Instytut Podstaw Informatyki PAN.

PęzIK Piotr (2015). Spokes - a search and exploration service for conversational corpus data. In Selected Papers from the CLARIN 2014 Conference, Jan ODIJK (ed.), 99-109. Linköping: Linköping University Electronic Press. [Spokes available on-line, URL: http://spokes.clarin-pl.eu; accessed December 15, 2016]

Przepiórkowski Adam (2000). Long distance genitive of negation in Polish. Journal of Slavic Linguistics 8, 119-158.

Quaglio Paulo, Biber Douglas (2006). The grammar of conversation. In The Handbook of English Linguistics, Bas AARTs and April McMahon (eds.), 692-723. Oxford: Blackwell.

Sornicola Rosanna (1981). Sul Parlato. Bologna: Il Mulino.

Szczegielniak Adam (2006). Two types of resumptive pronouns in Polish relative clauses. In Linguistic Variation Yearbook 5, Pierre PICA, Johan RoorYcK, Jeroen van Craenenbroeck (eds.), 165-185. Amsterdam: John Benjamins. 
Willis David (2013). Negation in the history of Slavonic languages. In The History of Negation in the Languages of Europe and the Mediterranean, vol. 1. Case Studies, David Willis, Christopher Lucas, Anne Breitbarth (eds.), 342-398. Oxford: Oxford University Press.

Zemskaja Elena A. (1973). Russkaja razgovornaja reč. Moscow: Nauka.

\section{Wojciech Guz}

Instytut Filologii Angielskiej

Katolicki Uniwersytet Lubelski Jana Pawła II

Al. Racławickie 14

20-950 Lublin

Poland

[wguz(at)o2.pl] 